\title{
Profil wydawnictwa ciągłego „Przekłady Literatur Słowiańskich"
}

\footnotetext{
„Przekłady Literatur Słowiańskich” to wydawnictwo ciagłe, które powstało na Wydziale Filologicznym w Instytucie Filologii Słowiańskiej Uniwersytetu Śląskiego w 2009 roku. Dotyczy problematyki teoretycznej, historycznoliterackiej i historycznokulturowej związanej z przekładem artystycznym na języki południowo- i zachodniosłowiańskie. Zadaniem serii jest rejestrowanie wydań i recepcji przekładów, zawiera studia omawiające specyfikę przekładu języków, które są ze sobą blisko spokrewnione, rozprawy poświęcone przekładowi jednej kultury na drugą za pośrednictwem literatury oraz prace o roli przekładu w komparatystyce. Tomy są wydawane w dwóch częściach. Pierwsza ma charakter dokumentacyjno-socjologiczny i zawiera bibliografię przekładów literatur słowiańskich na język polski i literatury polskiej na języki słowiańskie oraz ich recepcję, druga - krytyczno-interpretacyjna - dotyczy uogólnień teoretycznych. W każdym tomie znajdują się części: problemowa i bibliograficzna poświęcone przekładom polsko-słowiańskim (z literatury polskiej na języki: bułgarski, chorwacki, czeski, macedoński, łużycki, serbski, słowacki i słoweński) i słowiańsko-polskim (z literatur słowiańskich na język polski) oraz bibliografii przekładów, które zostały opublikowane po roku 1990. Wydawca zapewnia, że uzupełniana będzie bibliografia rejestrująca wcześniejsze lata.

Wydawnictwo Uniwersytetu Śląskiego w ramach serii „Przekłady Literatur Słowiańskich" opublikowało jak dotąd pięć książek, w tym trzy problemowe: Wybory translatorskie 1990-2006, t. 1, cz.1, red. B. Tokarz, Katowice 2009 (wyd. II 2010), ss. 334; Formy dialogu międzykulturowego $w$ przektadzie artystycznym, t. 2, cz. 1, red. B. Tokarz, Katowice 2011, ss. 319; Bariery kulturowe $w$ przekładzie artystycznym, t. 3, cz. 1, red. B. Tokarz, Katowice 2012, ss. 278 i dwie bibliograficzne: Bibliografia przektadów literatur stowiańskich (1990-2006), t. 1, cz. 2, red. B. Tokarz, Katowice 2010, ss. 202; Bibliografia przekładów literatur słowiańskich
} 
(1990-2006), t. 1, cz. 3, red. B. Tokarz, Katowice 2012, ss. 350. W druku jest tom 1, część 4, zawierający ostatni segment bibliografii przekładów literatur słowiańskich w latach 1990-2006, natomiast tom 4, część 1: Stereotypy w przektadzie artystycznym obecnie jest recenzowany.

Publikacja została skierowania do odbiorcy zainteresowanego południową i zachodnią Słowiańszczyzną, do studentów, przekładoznawców, kulturoznawców i tłumaczy (w tym polonistów). Artykuły publikowane w serii pisane są na ogół w języku polskim, ponieważ mimo międzynarodowego charakteru projektu celem serii jest, jak można sądzić, podniesienie kompetencji odbiorcy rodzimego w zakresie różnorodności kultur słowiańskich. Każdy artykuł zawiera dwa streszczenia: w języku, którego literatura dotyczy, i w języku angielskim ( $w$ obu językach są także podane słowa kluczowe).

W Polsce badania nad przekładem mają już swoją tradycję i kilka ośrodków uniwersyteckich legitymuje się poważnymi pracami w tym zakresie. Zważywszy na to, że dzieje polskiego przekładoznawstwa obejmują różne typy tłumaczeń, badanych w ujęciu językoznawczym, literaturoznawczym i częściowo kulturowym, warto wskazać, jakie miejsce zajmuje seria „Przekłady Literatur Słowiańskich” wśród publikacji slawistycznych oraz serii literaturoznawczych poświęconych przekładowi.

Całościową refleksją badawczą nie zostały dotąd objęte przekłady między poszczególnymi literaturami słowiańskimi, poza rosyjską i polską, a więc wypełnienie tej luki wydaje się potrzebne i uzasadnione. Wobec wewnętrznej różnorodności kultur słowiańskich studia nad nimi z perspektywy przekładoznawczej ujawniają zjawiska nieznane dotąd $\mathrm{w}$ teorii przekładu. Ponadto przybliżają problemy kulturowo-antropologiczne Słowiańszczyzny, zaprzeczając dziewiętnastowiecznemu stereotypowi o podziale kultury europejskiej na romańsko-germańską i słowiańską, co sugeruje monolityczność świata słowiańskiego. Pogląd taki prawdopodobnie mógł zaważyć na utrzymującej się względnej i niedostatecznej znajomości wzajemnej kultur słowiańskich. Przekład literacki jako forma dialogu międzykulturowego pokazuje, w jakim stopniu możliwe jest zrozumienie i porozumienie między nimi przy jednoczesnym zachowaniu różnic.

W serii „Przekłady Literatur Słowiańskich” porządek chronologiczny studiów nad przekładem został odwrócony. Wybór roku 1990 jako daty otwierającej publikację wiąże się $\mathrm{z}$ pewnością ze zmianami polityczno-ustrojowymi w statusie państwowym narodów słowiańskich, zapoczątko- 
wanymi w 1989 roku i, choć obie daty nie wskazują na konkretne fakty historyczne, wspólne dla wszystkich Słowian, to oznaczają okres powstawania i utwierdzania się nowych państwowości oraz stabilizacji ustrojowej, co w innym kontekście stawia pytania o tożsamość, różnicę, a również o możliwości komunikacji międzykulturowej, świadomej i chcianej. Przekład jest swoistym papierkiem lakmusowym, wskazującym na realizacje funkcji mediacyjnej w sytuacji kulturowej, politycznej i cywilizacyjnej ostatnich lat.

Wśród serii przekładoznawczych skupiających badaczy przekładów literatur obcych (w nieznacznej mierze słowiańskich) na język polski, należy wymienić: wielotomową i wieloaspektową serię katowicką „Studia o Przekładzie” pod redakcją Piotra Fasta, serię krakowsko-bielsko-bialską „Między Oryginałem a Przekładem" zapoczątkowaną przez Jadwigę Konieczną-Twardzikowa, a kontynuowana przez Jerzego Brzozowskiego i Marię Filipowicz-Rudek oraz serię gdańską „Przekładając Nieprzekładalne” pod redakcją Olgi i Wojciecha Kubińskich.

Seria „Przekłady Literatur Słowiańskich” jest pierwszą slawistyczną publikacją tego typu (nie licząc prac rusycystycznych). W wyraźny sposób ukazuje różnice i podobieństwa oraz dialog między kulturami słowiańskimi, prowadząc być może ku specyficznej komparatystyce słowiańskiej. Stawia sobie zadania zbliżenia i wzajemnego poznania kultur słowiańskich. Literatura słowiańska funkcjonuje jednak także w szerszym kontekście społecznym, politycznym czy międzykulturowym, dlatego autorzy opracowań odnoszą się również do kultur niesłowiańskich.

Tom I, część 1 serii poświęcony jest wyborom translatorskim lat 1990-2006 i ma układ odpowiadający relacjom przekładowym pomiędzy różnymi literaturami (przekłady polsko-bułgarskie i bułgarsko-polskie, chorwacko-polskie i polsko-chorwackie, czesko-polskie, macedońsko-polskie, serbsko-polskie i polsko-serbskie, słowacko-polskie, słoweńsko-polskie i polsko-słoweńskie oraz słoweńsko-czesko-polskie). Recenzowany tom serii „Przekłady Literatur Słowiańskich” oferuje różnorodne, wartościowe i pożyteczne opracowania. Zasadniczo występują tu trzy typy tekstów. W grupie pierwszej można wyodrębnić te, które w pewnym oglądzie historycznoliterackim, kulturowym i socjologicznym rzucają światło na działalność translatorską w szerszej perspektywie i zakresie chronologicznym (C. Juda, Rozrachunki po przełomie. Polskie przekłady z literatury butgarskiej po 1999 roku. Diagnozy i prognozy. Wspótczesność i tradycja; K. Bachneva, 
Literatura polska w przekładach na język butgarski. Czasopisma literackie w latach 1990-2007; Đ. Čilić Škeljo, I. Vidović Bolt, Literatura polska w chorwackich przekładach od 1990 r. do 2007 r.; J. Sobczak, Polski dramat $w$ Serbii w latach 1990-2006; L. Spyrka, Polskie przektady dramatu stowackiego w latach 1990-2005; B. Tokarz, Stoweńskie wybory literatury polskiej: przekłady z lat 1990-2006). Drugą grupę tekstów tworzą opracowania, które koncentrują się na problemach recepcyjnych i strategii translatorskiej (I. Likomanova, Butgarskie wybory z literatury polskiej (na materiale z prasy literackiej); J. Mleczko, Transformacje translatorskie w przektadzie butgarskiej bajki magicznej „Trzej bracia i złote jabłko” (kod estetyczny); L. Małczak, O polskich przektadach chorwackiej literatury wojennej-Dragutin Tadijanović: „Molba munji nebeskoj”; A. Gostomska, O strategii ttumaczenia na przyktadzie powieści „Ministerstwo bólu” Dubravki Ugrešić; J. Zarek, O polskich przektadach nowej czeskiej „powieści praskiej” (M. Ajvaza, D. Hodrovej, J. Topola); I. Mroczek, O recepcji ttumaczeń czeskiej literatury bestsellerowej w Polsce (na przyktadach ttumaczeń ksiażek Michala Viewegha, Ireny Obermannovej i Haliny Pawlovskiej). Trzecią grupę stanowią opracowania koncentrujące się na problematyce estetyki i wierności przekładu, przekładu w systemie literatury oraz zagadnień wiążących translatorykę z kontekstem teoretycznoliterackim i historycznoliterackim (M. Błaszak, Kategoria świadka w przekładzie prozy macedońskiej; M. Buczek, Stowacki realizm magiczny w polskim przekładzie; M. Gawlak, Poezja Gregora Strnišy w przekładzie Katariny Šalamun-Biedrzyckiej; A. Muszyńska, „Polskość” w stoweńskich przektadach Rozki Štefan; M. Kopczyk, Przyczynek do tematu: przekład $w$ systemie literatury. Przy okazji stoweńskiej wersji „Dziennika” Witolda Gombrowicza).

Tom 1, część 2 nosi tytuł Bibliografia przekładów literatur stowiańskich (1990-2006) i jej treść wypełniają: bibliografia przekładów słoweńsko-polskich i polsko-słoweńskich.

Tom 1, część 3 prezentuje bibliografię przekładów literatur słowiańskich (z lat 1990-2006), uwzględniając przekłady polsko-bułgarskie, polsko-chorwackie i polsko-serbskie, a także przekłady z wymienionych języków słowiańskich na język polski.

Tom 2 i tom 3 poświęcone zostały relacjom interkulturowym przekładu artystycznego. Tom 2, część 1 nosi tytuł Formy dialogu międzykulturowego w przekładzie artystycznym, a tom 3, część 1 - Bariery kulturowe 
$w$ przekładzie artystycznym. Pierwszy z omawianych tomów (Formy dialogu międzykulturowego $w$ przektadzie artystycznym) nie ma wystarczająco spójnego wewnętrznego podziału rozdziałów, ale przynosi niezwykle interesujące opracowania z zakresu relacji międzykulturowych w przekładzie artystycznym, które w świetle opublikowanych tekstów oznaczają tropienie podobieństw i różnic interkulturowych między oryginałami różnych dzieł, jak i interkulturowo uwarunkowanych relacji translatorskich między oryginałem a przekładem. Innymi kluczami poszukiwania równoznaczności przekładów w recenzowanych tekstach są: leksyka i stylistyka (L. Vitová, Stylizacja na potoczność w przektadzie literatury czeskiej na język polski); semantyka i pragmatyka komunikacyjna (M. Czerwiński, Dialog znaków i kodów: między oryginatem a polskim przekładem $w$ powieści Miljenko Jergovicia „Ruta Tannenbaum”); matryce semantyczne i poznawcze (L. Miodyński, Kulturowe matryce semantyczne - wiersz macedoński $w$ refleksie polskim $i$ chorwackim); fascynacja obcością przy jednoczesnym podkreślaniu własnej odrębności (J. Mleczko, Granice egzotyzacji (na przyktadzie polskiego przekładu „Indże” Jordana Jovkova); A. Kovacheva, Obraz Turka osmańskiego - między mitem, historiq a przektadem (na marginesie dwóch powieści historycznych Wery Mutafczijewej); L. Małczak, Obraz katolików i muzutmanów w polskich przekładach opowiadania Andricia „U musafirhani”.

Wielokulturowość w przypadku Słowiańszczyzny Południowej oznacza przede wszystkim odmienności w sferze mentalnej powstałej na styku bizantynizmu, orientalizmu i okcydentalizmu, będące efektem dziedzictwa historycznego, kulturowego i konfesyjnego. Dialog międzykulturowy odbywa się w przestrzeni tekstu przekładu oraz w przestrzeni kultury przyjmującej. Oznacza to, że związki międzykulturowe tworzą wewnątrztekstowe zależności (sieć odniesień pomiędzy oryginałem i przekładem oraz literaturą rodzimą i literaturą przekładu), a także relacje zewnętrzne $\mathrm{z}$ innymi tekstami kultury. Te problemy stały się przedmiotem refleksji kilku opracowań, m.in.: I. Mroczek, „Gottland” Mariusza Szczygła w czeskim przektadzie i jego czeska recepcja; B. Tokarz, $W$ perspektywie poznania i projekcji. O polskim przekładzie zbioru esejów Draga Jančara „Terra incognita".

Tom 3, część 1, poświęcony tytułowym barierom kulturowym w przekładzie artystycznym, podejmuje nie tylko problem ograniczeń translatorskich, ale także sąsiedztwa, modelu kulturowego i jego uwarunkowań, 
dyskursu estetycznego i aksjologicznego w tłumaczeniu oraz jego ram interpretacyjnych. Kwestia barier w przekładzie związana jest $\mathrm{z}$ konfrontacyjnym rozumieniem przekładu, opartym na „,podwójności” tekstu wtórnego. Edward Balcerzan definiuje go jako literaturę z literatury, Anna Legeżyńska tekst z tekstu, a Elżbieta Tabakowska - ekwiwalencję doświadczenia. Zagadnienia te podejmują m.in.: I. Stanios, Transkulturowość oryginału w przektadzie (na przyktadzie powieści „Derwisz i śmierć” Mešy Selimovicia; P. Pycia, Przekraczajac granice. Problem przektadu wulgaryzmów i przekleństw; M. Buczek, Bariery kulturowe w stowackim przekładzie „Ferdydurke” Witolda Gombrowicza; B. Tokarz, Gombrowicz $w$ Stowenii: ramy interpretacyjne czasu i przestrzeni kulturowej.

Wydawnictwo ciagłe „Przekłady Literatur Słowiańskich” posiada: indeksację w bazie CEEOL, międzynarodową radę redakcyjną (w składzie: prof. dr hab. Edward Balcerzan - Polska; doc. dr hab. Nikolaj Jež - Słowenia; prof. dr hab. Zvonko Kovač - Chorwacja; prof. dr hab. Eva Mala Słowacja; doc. dr hab. Martina Ožbot - Słowenia; prof. dr hab. Ivo Pospišil - Czechy; prof. dr hab. Tone Smolej - Słowenia, prof. dr hab. Elżbieta Tabakowska - Polska), redaktorów językowych: Iljana Genev-Puhaleva - język bułgarski (Bułgaria), Srdjan Orsić - język serbski (Serbia), Elena Micevska - język macedoński (Macedonia), Robert Bebek - język chorwacki (Chorwacja), Radek Jerabek - język czeski (Czechy), Andres Gootsova - język słowacki (Słowacja), Tina Jugović - język słoweński (Słowenia), Eric Starnes - język angielski (Wielka Brytania) i redaktora tematycznego - Leszek Małczak (Polska).

Wydawnictwo ciagłe „Przekłady Literatur Słowiańskich” współpracuje z polskimi (m.in. Kraków, Poznań) i zagranicznymi (Bułgaria, Chorwacja, Czechy, Macedonia, Serbia, Słowacja i Słowenia) ośrodkami zajmującymi się przekładoznawstwem.

„Przekłady Literatur Słowiańskich” na dobre zaistniały w slawistycznej i humanistycznej przestrzeni zarówno polskiego, jak i międzynarodowego życia uniwersyteckiego, wiążą dotąd odległe płaszczyzny - estetyczną, recepcyjną i interkulturową, uświadamiając także zewnętrzne konteksty funkcjonowania dzieła literackiego, granice rodzimego języka, poza które wykracza, jak również rzeczywistości społecznej, politycznej kulturowej i konfesyjnej.

Bogusław Zieliński 